\title{
Genetic Divergence of Turkish Apis mellifera Subspecies Based on Sequencing of ND5 Mitochondrial Segment
}

by

\author{
Fulya Özdil ${ }^{1 *} \&$ Fatma İlhan ${ }^{1}$
}

\begin{abstract}
Mitochondrial DNA sequence variation can be used to infer honey bee evolutionary relationships. In this study, DNA sequence diversity in the ND5 region of the mitochondrial genome was investigated in 93 samples of Apis mellifera from 15 different populations in Turkey. Five novel haplotypes were revealed for the ND5 gene segment of Turkish honeybees. The number of variable sites found was 6 for this region while 2 were parsimony informative sites. The average pairwise genetic distances were $0.3 \%$ for ND5 gene. In this study, the NJ tree of ND5 gene segment were constructed with the published sequences of Apis mellifera haplotypes. This study expands the knowledge about the mitochondrial ND5 region in Apis mellifera and it is also the first comprehensive sequencing analysis of ND5 region in Turkish honeybees.

Key words: Apis mellifera L., DNA sequence diversity, ND5, Turkey

\section{INTRODUCTION}

The honey bee, Apis mellifera L., occurs naturally in Europe, the Middle East and Africa (Ruttner 1988). From morphometric and molecular studies, the 29 subspecies of the honey bee, Apis mellifera L., are grouped into five evolutionary lineages: $\mathrm{M}$ from northern and western Europe and northern Africa, A from southern and central Africa, C from the northern Mediterranean region and eastern Europe, $\mathrm{O}$ from the eastern Mediterranean and the Near and Middle East region, and Y from the east African country of Ethiopia (Ruttner 1988; Hall and Smith 1991; Garnery et al. 1992; Arias and Sheppard 1996; Kauhausen-Keller et al. 1997; Franck et al. 2000, 2001).
\end{abstract}

\footnotetext{
${ }^{1}$ Department of Animal Science, Faculty of Agriculture, Selçuk University, Konya, Turkey *Corresponding author: fulyaozdil@selcuk.edu.tr

The department where the study was conducted:

Selçuk University, Faculty of Agriculture, Major of Biometry \& Genetics, 42075 Konya-Turkey
} 
Based on morphometrics, the Near Eastern subspecies, Anatolian ( $A . m$. anatoliaca), Caucasian (A.m. caucasica) and Iranian ( $A$. m. meda), had been grouped within the O branch (Ruttner 1988; Kauhausen-Keller et al. 1997), however mtDNA analysis showed that they belonged to the Clineage (Smith et al. 1997; Palmer et al. 2000; Franck et al. 2000, 2001; Kandemir et al. 2006; Özdil et al.2009a, 2009b; Bouga et al. 2011). Ruttner's (1988) morphometric analyses concluded that $A$. m. anatoliaca, $A$. $m$. caucasica and $A$. $m$. meda exist in Turkey. Nearly all of Turkey is occupied by $A$. m. anatoliaca. A. m. caucasica is found in the northeastern part of Turkey and $A$. m. meda is found in the southeastern part of Turkey. Recently, the mitochondrial studies of Turkish honeybees had also shown that $A$. m. carnica is found in the European part of Turkey called Thrace (Palmer $e t a l .2000$ ) and $A$. m. syriaca is found in the south part of the country near the Hatay region (Kandemir et al. 2006).

The mitochondrial genome has been a useful molecule for population genetic studies of Apis mellifera L. Length and sequence variations within the mitochondrial genome of honeybees have been particularly useful in differentiating evolutionary lineages and groups of subspecies (Hall and Smith 1991; Garnery et al. 1992, 1993; Franck et al. 2000; Palmer et al. 2000). Apis mellifera ligustica was the first Hymenopteran subspecies for which the whole mitochondrial genome has been sequenced (Crozier and Crozier 1993). To date, many mitochondrial regions, of which the $\mathrm{RNA}^{\mathrm{leu}}$-COII region (formerly COI-COII intergenic region) (Garnery et al. 1992, 1993; Franck et al. 2000; De la Rua et al.2001, 2004; Palmer et al. 2000, Sušnik et al. 2004; Kozmus et al. 2007; Muňoz et al. 2009; Nedić et al. 2009; Özdil et al. 2009a; Magnus and Szalanski 2010; Szalanski and Magnus 2010) was the first, have been sequenced and phylogenetic relationships among Apismellfera subspecies has been described. But we still have little knowledge about the other mitochondrial regions. The ND5 gene segment was first sequenced in Greek honeybees and this is the only study of the phylogenetic relationships among East European subspecies (Martimianakis et al. 2011).

The objective of this research was to determine the genetic diversity and phylogenetic relationships of Apis mellifera subspecies of Turkey as determined by sequencing of ND5 gene segment. Length variations and nucleotide substitutions found in this gene segment were compared with the other mitochondrial surveys and such results could be also useful in determining the genetic structure of honey bees. 


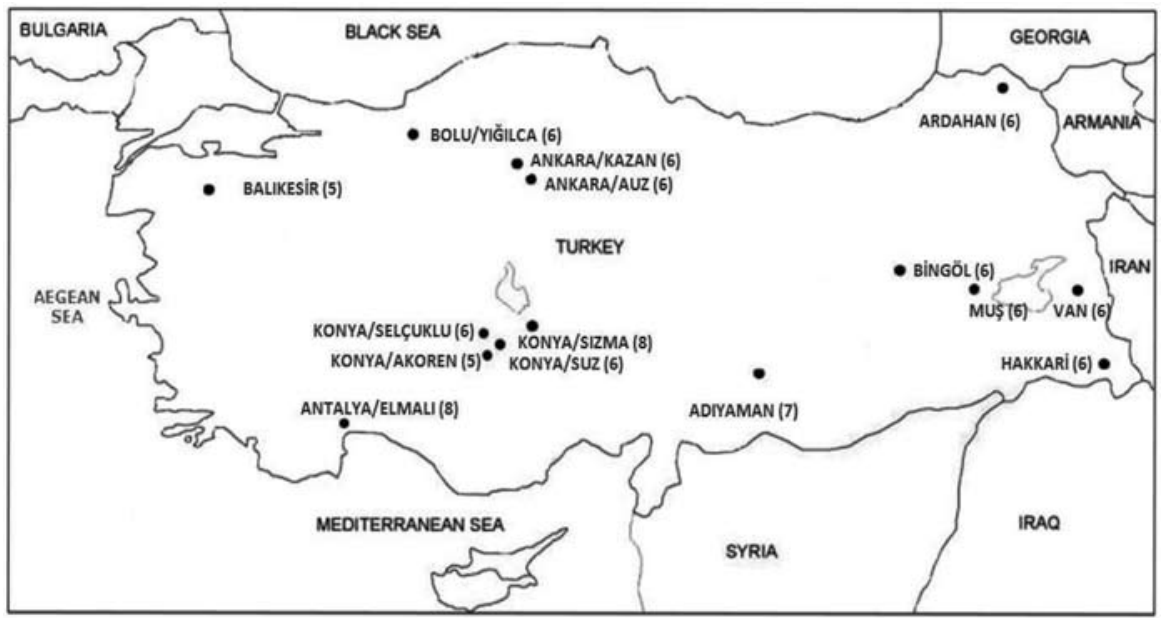

Fig. 1. Sampling locations in Turkey. Number in parenthesis show the number of colonies sequenced at each site.

\section{MATERIALS AND METHODS}

\section{Sampling and DNA extraction}

A total of 93 honey bees each representing a different colony was collected from 15 widespread locations in Turkey (Fig. 1, Table 1). Workers were collected in 95\% ethanol and subsequently air-dried. Total DNA was extracted from each bee's thorax according to Hall (1990). The concentration and purification of genomic DNA was quantified with a NanoDrop ND-1000 spectrophotometer, and 20 ng of genomic DNA was used for the PCR.

\section{Sequence Analysis}

The ND5 mitochondrial gene segment was amplified according to Bouga et al. (2005). The PCR products were purified using a gel purification kit (QIAGEN) and sequenced in both directions on an ABI Prism 3130 automated sequencer (Applied Biosystems) using standard protocols. Sequences were aligned with the computer program Clustal X (Thompson et al. 1997). For estimates of the similarity index and evolutionary divergence between DNA sequences MEGA5 Software was used. Resulting in a consensus of the phylogenetic tree, the methods of Maximum Parsimony (MP) and Neighbor-Joining (NJ) analysis were performed using the same software (Tamura et al. 2011). 
Table 1. Sampling localities, geographical positions and number of colonies used for sequencing.

\begin{tabular}{lcccc}
\hline \multicolumn{1}{c}{ Locations } & $\begin{array}{c}\text { Abbreviation of } \\
\text { the locations }\end{array}$ & Geographical position & $\begin{array}{c}\text { \# Colonies Analyzed } \\
\text { for sequence analysis }\end{array}$ \\
\hline ADIYAMAN & ADI & $37^{\circ} 46^{\prime} \mathrm{N}$ & $38^{\circ} 16^{\prime} \mathrm{E}$ & 7 \\
ARDAHAN & ARD & $41^{\circ} 03^{\prime} \mathrm{N}$ & $42^{\circ} 42^{\prime} \mathrm{E}$ & 6 \\
ANKARA / KAZAN & KAZ & $39^{\circ} 58^{\prime} \mathrm{N}$ & $32^{\circ} 52^{\prime} \mathrm{E}$ & 6 \\
ANKARA / AUZ* & AUZ & $40^{\circ} 12^{\prime} \mathrm{N}$ & $32^{\circ} 411^{\prime} \mathrm{E}$ & 6 \\
ANTALYA / ELMALI & ELM & $36^{\circ} 44^{\prime} \mathrm{N}$ & $29^{\circ} 56^{\prime} \mathrm{E}$ & 8 \\
BALIKESIR & BAL & $39^{\circ} 39^{\prime} \mathrm{N}$ & $27^{\circ} 53^{\prime} \mathrm{E}$ & 5 \\
BINGÖL & BIN & $39^{\circ} 00^{\prime} \mathrm{N}$ & $40^{\circ} 41^{\prime} \mathrm{E}$ & 6 \\
BOLU / YIĞILCA & $\mathrm{BOL}$ & $40^{\circ} 58^{\prime} \mathrm{N}$ & $31^{\circ} 27^{\prime} \mathrm{E}$ & 6 \\
HAKKARI & $\mathrm{HAK}$ & $37^{\circ} 35^{\prime} \mathrm{N}$ & $43^{\circ} 34^{\prime} \mathrm{E}$ & 6 \\
KONYA / AKÖREN & AKO & $37^{\circ} 27^{\prime} \mathrm{N}$ & $32^{\circ} 22^{\prime} \mathrm{E}$ & 5 \\
KONYA / SELÇUKLU & SEL & $37^{\circ} 57^{\prime} \mathrm{N}$ & $32^{\circ} 26^{\prime} \mathrm{E}$ & 6 \\
KONYA / SIZMA & SIZ & $38^{\circ} 05^{\prime} \mathrm{N}$ & $32^{\circ} 24^{\prime} \mathrm{E}$ & 8 \\
KONYA / SUZ $* *$ & SUZ & $38^{\circ} 02^{\prime} \mathrm{N}$ & $32^{\circ} 30^{\prime} \mathrm{E}$ & 6 \\
MUŞ / VARTO & MUS & $39^{\circ} 17^{\prime} \mathrm{N}$ & $41^{\circ} 12^{\prime} \mathrm{E}$ & 6 \\
VAN / GEVAŞ & VAN & $38^{\circ} 18^{\prime} \mathrm{N}$ & $43^{\circ} 06^{\prime} \mathrm{E}$ & 6 \\
\hline
\end{tabular}

*AUZ: The Apiary of the Ankara University

${ }^{*}$ SUZ: The Apiary of the Selçuk University

For the construction of the phylogenetic trees, we used Apis cerena (accession number: NC_014295) sequences retrieved from Genbank, as outgroup in order to root the trees. The sequences obtained in this study have been deposited to Genbank with accession numbers JN410833 to JN410837. The resulting sequences were compared to published sequences available in Genbank.

\section{RESULTS}

The sizes of the PCR-amplified ND5 segment for all populations studied were found to be $782 \mathrm{bp}$ (primers excluded). Five novel haplotypes were revealed for the ND5 gene segment in Turkish honeybees. The number of variable sites was found to be 6 for this region 2 of which were parsimony informative sites. The average pairwise genetic distances were $0.3 \%$ for ND5 gene (Kimura 1980).

Table 2 lists the different haplotypes of the ND5 gene found in this study and in Martimianakis et al. 2011. The sequence information, Genbank accession numbers and variable sites of these haplotypes and additional new 
haplotypes that are found in this study are summarized in Table2. The mtDNA nucleotide positions are taken from Crozier and Crozier (1993).

The trees drawn by Maximum Parsimony and Neighbor-Joining analysis exhibited nearly the same topology for ND5 mtDNA region so only the NJ tree is presented here. At population level, sequencing of ND5 mitochondrial region has been studied less than the other mitochondrial regions. Only Martimianakis et al., (2011) gives information about sequencing of this region in samples from Greece and some East European Countries. The phylogenetic tree of Greek and Turkish honey bee haplotypes constructed by the NJ method is shown in Fig. 2.

\section{DISCUSSION}

Several mitochondrial studies of Turkish honey bee populations have been conducted (Smith et al. 1997; Palmer et al. 2000; Kandemir et al. 2006, Özdil et al. 2009a). With restriction digests, nearly all Turkish colonies analyzed previously by the other surveys were found to belong to the C Mediterranean

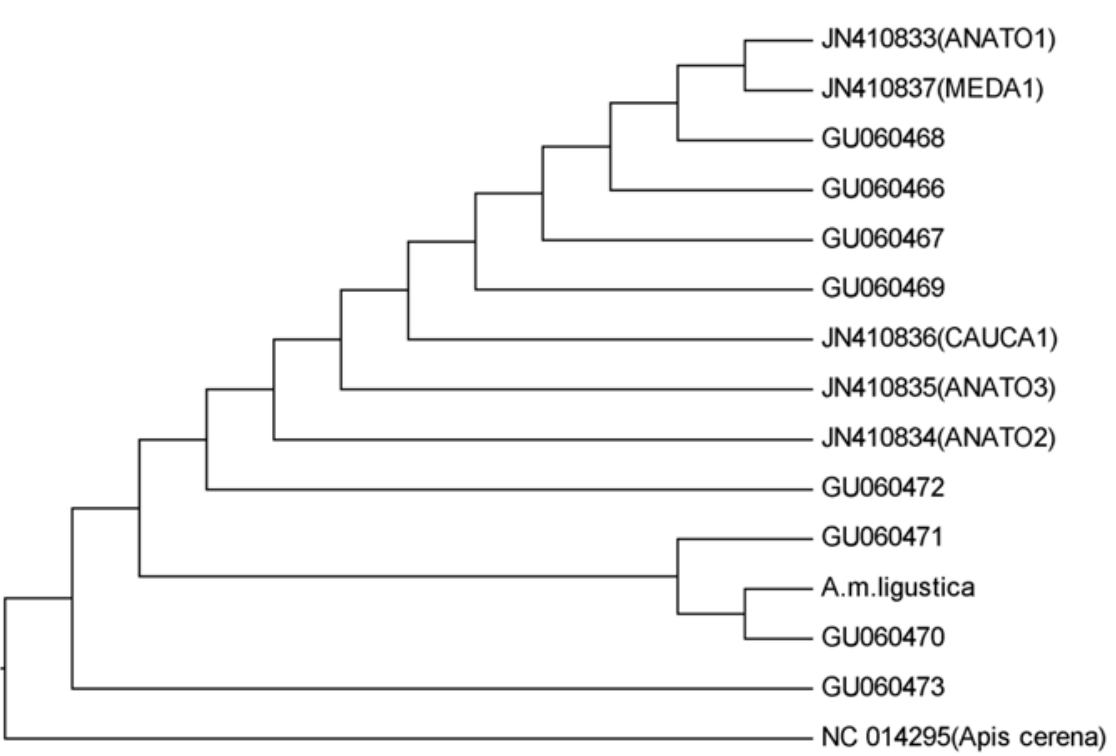

Fig. 2. Neighbour-Joining dendogram based on ND5 sequences of Apismellifera haplotypes. Sequences obtained in this study are written in capital letters. 


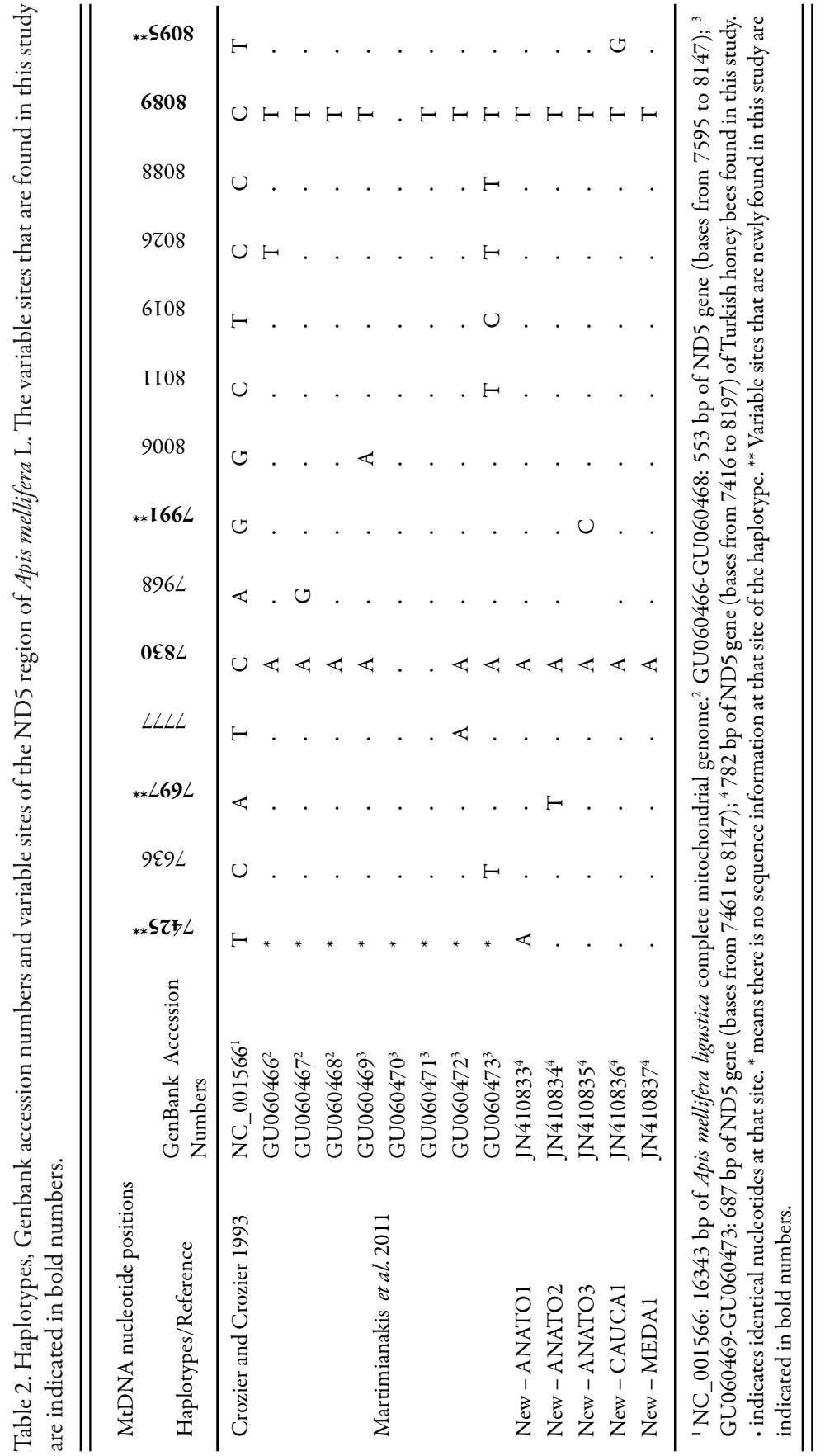


lineage. This finding was expected because the Turkish populations consist mainly of $A$. m. anatoliaca, A.m. caucasica and A. m. meda.

Previously, we had shown the phylogenetic relationships and PCR-RFLP profile of Turkish honey bees using several restriction enzymes in both the mitochondrial and nuclear genome of Apismellifera (Özdil etal.2009,2011). In this study we presented a comprehensive sequencing analysis of the ND5 mitochondrial gene segment to verify genetic divergence in Turkish honey bee populations. We found five different haplotypes for the ND5 gene segment.

Sequencing of the ND5 mitochondrial region has been studied less than the other mitochondrial regions. Only eight different haplotypes of Apismellifera were reported in this region. Here we added five new haplotypes in this study (Table 2). Three came from the Anatolian geographical locations, one from each Iranian and Caucasian geographical location. While ANATO1 (JN410833) haplotype was only obtained in some of the honeybees from SIZ population, ANATO2 (JN410834) was found in both SIZ and ELM populations. These two haplotypes were found to be the rarest Anatolian haplotypes whereas ANATO3 (JN410835) haplotype was found in a wide geographical area such as BAL, BOL, AKO, SEL and SUZ. Caucasian haplotype, CAUCA1 (JN410836), was obtained from ARD, KAZ and AUZ where ARD was the center of Caucasian honey bees. And MEDA1 (JN410837) haplotype was found in honey bees from the South-East part of Turkey where mostly $A$. m. meda is found.

The base substitutions at position $7830(\mathrm{C} \rightarrow \mathrm{A})$ and $8089(\mathrm{C} \rightarrow \mathrm{T})$ which were reported in Martimianakis et al. (2011), were observed in all of the Turkish honeybees in this study. The NJ dendogram (Fig. 2) based on ND5 sequences of the two surveys showed that that these races cannot be discriminated from each other since all of them belong to East European (C) lineage. But it is seen that Haplotype 1-4 (Genbank records: GU060466-GU060469) in Martimianakis et al. (2011) and the haplotypes that are found in Turkish honeybees are much closer than the other haplotypes.

In addition to previous findings of the ND5 gene, here we reported sequencing of this mitochondrial DNA gene segment in Turkish honey bees and compared these results with other East European races. Our data showed 
that samples from SIZ (Konya/Sizma) and ARD (Ardahan), having unique haplotypes, maintain their native origin and they might be pure A. m. Anatoliaca and $A$. $m$. caucasica, respectively. High migratory beekeeping activity and the use of Caucasian queens for queen rearing in Turkey have resulted in the loss of genetic diversity. So it is highly important to identify the genetic structure of local honey bee races and improve strategies to conserve them in their areas.

\section{ACKNOWLEDGMENTS}

The authors would like to thank Prof. Dr. Saim BOZTEPE, (Selçuk University, Faculty of Agriculture) and Prof. Dr. Mehmet Ali YILDIZ (Ankara University, Faculty of Agriculture) for providing insight and guidance during various phases of this project. The authors also would like to thank Hüseyin BAYIR for help in collecting samples from central region of Turkey.

\section{REFERENCES}

Arias, M.C. \& W.S. Sheppard 1996. Molecular phylogenetics of honey bee subspecies (Apis mellifera L.) inferred from mitochondrial DNA sequence. Molecular Phylogenetics and Evolution 5: 557-566.

Bouga, M., P.C. Harizanis, G. Kilias \& S. Alahiotis 2005. Genetic divergence and phylogenetic relationships of honey bee Apis mellifera (Hymenoptera: Apidae) populations from Greece and Cyprus using PCR-RFLP analysis of three mtDNA segments. Apidologie 36: 335-344.

Bouga, M., C. Alaux, M. Bienkowska, R. Büchler, N.L. Carreck, E. Cauia, R. Chlebo, B. Dahle, R. Dall'olio, P. De La Rúa, A. Gregorc, E. Ivanova, A. Kence, M. Kence, N. Kezic, H. Kiprijanovska, P. Kozmus, P. Kryger, Y. Le Conte, M. Lodesani, A. M. Murilhas, A. Siceanu, G. Soland, A. Uzunov \& J. Wilde 2011. A review of methods for discrimination of honey bee populations as applied to European beekeeping. Journal of Apicultural Research 50(1): 51-84.

Crozier, R.H.\&Y.C.Crozier 1993. The mitochondrial genome of the honeybee Apismellifera: complete sequence and genome organization. Genetics 133: 97-117.

De la Rúa, P., J. Galián, J. Serrano \& R.F.A. Moritz 2001. Genetic structure and distinctness of Apis mellifera L. populations from the Canary Islands. Molecular Ecology 10: 1733-1742.

De la Rúa, P., R. Hernández-Garcia, B.V. Pedersen, J. Galián \& J. Serrano 2004. Molecular diversity of honeybee Apis mellifera iberica L. (Hymenoptera: Apidae) from western Andalusia. Archiv Zootec 53: 195-203.

Franck, P., L. Garnery, M. Solignac \& J.-M. Cornuet 2000. Molecular confirmation of a fourth lineage in honeybees from the near east. Apidologie 31: 167-180. 
Franck, P., L. Garnery, A.Loiseau, B.P. Oldroyd, H.R. Hepburn, M. Solignac \& J.-M. Cornuet 2001. Genetic diversity of the honeybee in Africa: microsatellite and mitochondrial data. Heredity 86: 420-430.

Garnery, L., J.-M. Cornuet \& M. Solignac 1992. Evolutionary history of the honey bee Apis mellifera inferred from mitochondrial DNA analysis. Mol. Ecol. 1: 145-154.

Garnery, L., M. Solignac, G. Celebrano \& J.-M. Cornuet 1993. A simple test using restricted PCR amplified mitochondrial DNA to study the genetic structure of Apis mellifera. Experientia 49: 1016-1021.

Hall, H.G. 1990. Parental analysis of introgressive hybridization between African and European honeybees using nuclear DNA RFLPs. Genetics 125: 611-621.

Hall, H.G. \& D.R. Smith 1991. Distinguishing African and European honeybee matrilines using amplified mitochondrial DNA. Proc. Natl Acad. Sci. USA 88: 4548-4552.

Kandemir, I., M. Kence, W.S. Sheppard, A. Kence 2006. Mitochondrial DNA variation in honey bee (Apis mellifera L.) populations from Turkey. Journal of Apicultural Research and Bee World 45 (1): 33-38.

Kauhausen-Keller, D, F. Ruttner \& R. Keller 1997. Morphometric studies on the microtaxonomy of the species Apis mellifera L. Apidologie 28: 295-307.

Kimura, M. 1980. A simple method for estimating evolutionary rates of base substitutions through comparative studies of nucleotide sequences. Journal of Molecular Evolution 16: $111-120$.

Kozmus, P., J. Stevanović, Z. Stanimirović, V. Stojić, Z. Kulišić \& V. Meglič 2007. Analysis of mitochondrial DNA in honeybees (Apis mellifera) from Serbia. Acta Vet. 57: 465-476.

Magnus, R. \& A.L. Szalanski 2010. Genetic Evidence for Honey Bees (Apis mellifera L.) of Middle Eastern Lineage in the United States. Sociobiology 55: 285-296.

Martimianakis, S., E. Klossa-Kilia, M. Bouga \& G. Kilias 2011. Phylogenetic relationships of Greek Apis mellifera subspecies based on sequencing of mtDNA segments (COI and ND5). Journal of Apicultural Research 50 (1): 42-50.

Muňoz, I., R. Dall'Olio, M. Lodesani \& P. De la Rúa 2009. Population genetic structure of coastal Croatian honeybees (Apis mellifera carnica). Apidologie 40: 617-626.

Nedić, N.,L.Stanisavljević, M. Mladenović, J.Stanisavljević2009. Molecular characterization of the honeybee Apis mellifera carnica in Serbia. Arch. Biol. Sci., Belgrade 61 (4): 587-598.

Özdil ,F., M.A. Yıldız \& H.G. Hall 2009a. Molecular Characterization of Turkish Honey Bee Populations (Apis mellifera L.) Inferred from Mitochondrial DNA RFLP and Sequence Results. Apidologie 40 (5): 570-576.

Özdil, F., B. Fakhri, H. Meydan, M.A. Yıldız \& H.G. Hall 2009b. Mitochondrial DNA variation in the COI-COII intergenic region among Turkish and Iranian Honey Bees (Apis mellifera L.). Biochemical Genetics 47: 717-721.

Özdil,F., H. Meydan, M.A. Yıldız \& H.G. Hall 2011. Genetic Diversity of Turkish Honey Bee Populations Based on RFLPs at a Nuclear DNA Locus. Sociobiology 58(3): 719-731. 
Palmer, M.R., D.R. Smith \& O. Kaftanoğlu 2000. Turkish honeybees: Genetic variation and evidence for a fourth lineage of Apis mellifera mtDNA. J. Hered. 91: 42-46.

Ruttner, F. 1988. Biogeography and Taxonomy of Honeybees.Springer-Verlag, Berlin. 284 pp.

Smith, D.R., A. Slaymaker, M. Palmer \& O. Kaftanoğlu 1997. Turkish honeybees belong to the east Mediterranean mitochondrial lineage. Apidologie 28: 269-274.

Sušnik, S., P. Kozmus, J. Poklukar \& V.Meglić2004. Molecular characterization of indigenous Apis mellifera carnica in Slovenia. Apidologie 35: 623-636.

Szalanski,A.L. \& R.M. Magnus 2010. Mitochondrial DNA characterization of Africanized honeybee (Apismellifera L.) populations from the USA. Journal of Apicultural Research and Bee World 49(2): 177-185.

Tamura, K., D. Peterson, N. Peterson, G. Stecher, M. Nei \& S. Kumar 2011. MEGA5: Molecular Evolutionary Genetics Analysis using Maximum Likelihood, Evolutionary Distance, and Maximum Parsimony Methods. Molecular Biology and Evolution 28(10): 2731-2739.

Thompson, J.D., T.J. Gibson, F. Plewniak, F. Jeanmougin \& D.G. Higgins 1997. The CLUSTAL_X windows interface: flexible strategies for multiple sequence alignment aided by quality analysis tools. Nucleic Acids Research 25: 4876-4882.

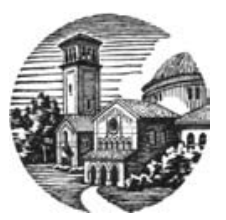

